\title{
Review
}

Physiology

Published online: November 6, 2014

\section{Mineralocorticoid and SGK1-Sensitive Inflammation and Tissue Fibrosis}

\author{
Ferruh Artunc $^{\mathrm{a}}$ Florian Lang ${ }^{\mathrm{b}}$ \\ Departments of ${ }^{\mathrm{a}}$ Internal Medicine and ${ }^{\mathrm{b}}$ Physiology, University of Tübingen, Tübingen, Germany
}

\section{Key Words}

Mineralocorticoid receptor $\cdot \mathrm{T}_{H} 17$ cells $\cdot$ TGF- $\beta$. SGK1 .

Connective tissue growth factor

\begin{abstract}
Effects of mineralocorticoids are not restricted to regulation of epithelial salt transport, extracellular volume and blood pressure; mineralocorticoids also influence a wide variety of seemingly unrelated functions such as inflammation and fibrosis. The present brief review addresses the role of mineralocorticoids in the orchestration of these latter processes. Mineralocorticoids foster inflammation as well as vascular, cardiac, renal and peritoneal fibrosis. Mechanisms involved in mineralocorticoid-sensitive inflammation and fibrosis include the serum- and glucocorticoid-inducible kinase 1 (SGK1), which is genomically upregulated by mineralocorticoids and transforming growth factor $\beta$ (TGF- $\beta$ ), and stimulated by mineralocorticoid-sensitive phosphatidylinositide 3-kinase. SGK1 upregulates the inflammatory transcription factor nuclear factor- $\mathrm{KB}$, which in turn stimulates the expression of diverse inflammatory mediators including connective tissue growth factor. Moreover, SGK1 inhibits the degradation of the TGF- $\beta$-dependent transcription factors Smad2/3. Mineralocorticoids foster the development of
\end{abstract}

$\mathrm{T}_{\mathrm{H}} 17$ cells, which is compromised following SGK1 deletion. Excessive SGK1 expression is observed in a wide variety of fibrosing diseases including lung fibrosis, diabetic nephropathy, glomerulonephritis, obstructive kidney disease, experimental nephrotic syndrome, obstructive nephropathy, liver cirrhosis, fibrosing pancreatitis, peritoneal fibrosis, Crohn's disease and celiac disease. The untoward inflammatory and fibrosing effects of mineralocorticoids could be blunted or even reversed by mineralocorticoid receptor blockers, which may thus be considered in the treatment of inflammatory and/or fibrosing disease.

(c) 2014 S. Karger AG, Basel

\section{Introduction}

Mineralocorticoids are decisive hormones in the regulation of extracellular volume homeostasis [1-3]. They are released following extracellular volume depletion and restore extracellular volume by stimulating salt intake [4, 5] and curtailing renal salt loss [2]. Extracellular volume expansion increases cardiac output and thus blood pressure $[1,6]$. However, mineralocorticoids participate in the regulation of a wide variety of further functions [7]. The present brief synopsis addresses the role of mineralo-

\section{KARGER}

E-Mail karger@karger.com

www.karger.com/nep
(C) 2014 S. Karger AG, Basel

$1660-2137 / 14 / 1282-0035 \$ 39.50 / 0$
Prof. Florian Lang

Department of Physiology, University of Tübingen

Gmelinstrasse 5

DE-72076 Tübingen (Germany)

E-Mail florian.lang@uni-tuebingen.de 
corticoids in the regulation of inflammation and tissue fibrosis. Specific emphasis will be placed on the role of the serum- and glucocorticoid-inducible kinase 1 (SGK1) in the mineralocorticoid action on inflammation and fibrosis. The reader is encouraged to consult earlier, more extensive reviews on mineralocorticoids and inflammation as well as tissue fibrosis [8-17].

\section{Effect of Mineralocorticoids on Inflammation and Fibrosis}

Mineralocorticoid and salt excess in rats lead to the activation of $\mathrm{T}_{\mathrm{H}}$ 17-helper cells in several tissues including the heart and kidneys [18]. The $\mathrm{T}_{\mathrm{H}} 17$-helper cells upregulate the pro-inflammatory cytokines GM-CSF, TNF- $\alpha$ and interleukin (IL)-2 [19]. The effect of mineralocorticoids on $\mathrm{T}_{\mathrm{H}} 17$ cell abundance is reversed by spironolactone treatment [18]. Application of anti-IL-17 to mineralocorticoid/salt-treated rats blunts the arterial hypertension, renal and cardiac expression of profibrotic and pro-inflammatory mediators as well as collagen deposition [18]. Mineralocorticoids further amplify activation of blood platelets [20], which in turn participate in vascular inflammation [21,22].

The mineralocorticoid receptor is expressed in vascular smooth muscle cells and participates in vascular remodeling [23]. Mechanisms involved in mineralocorticoid regulation of vascular function include generation of reactive oxygen species by nicotinamide adenine dinucleotide phosphate oxidase and by mitochondria [24, 25], Rho-kinase signaling [23, 25, 26], activation of epidermal growth factor receptor [27], stimulation of vascular endothelial growth factor type 1 receptor [23] and galectin signaling [23]. Mineralocorticoids are effective by influencing both genomic and nongenomic mechanisms [28].

Mineralocorticoids stimulate vascular [10, 23, 24, 2931], cardiac [8, 24, 29, 32-40], renal [24, 26, 36, 41-43], peritoneal $[14,17]$ and pancreatic [44] fibrosis.

\section{Role of SGK1 in Mineralocorticoid-Sensitive Inflammation and Fibrosis}

The inflammatory signaling of mineralocorticoids involves SGK1 [7, 45]. Mineralocorticoids are strong stimulators of SGK1 expression [46] and stimulate the phosphoinositide 3-kinase pathway [47, 48], which in turn activates SGK1 [46]. SGK1 expression is further upregulated by an increase in extracellular $\mathrm{NaCl}$ concentration
$[45,49,50]$, an effect involving p38/MAPK [46]. The kinase inactivates the transcription factor Foxol, which is in turn required for IL-23 receptor expression [50]. Via this receptor, IL-23 stimulates the generation of IL17-producing $\mathrm{CD}^{+}$-helper $\mathrm{T}$ cells $\left(\mathrm{T}_{\mathrm{H}} 17\right.$ cells). The $\mathrm{T}_{\mathrm{H}} 17$ cells play a decisive role in autoimmune disease [19]. $\mathrm{T}_{\mathrm{H}} 17$ cells are further upregulated by increased extracellular $\mathrm{NaCl}$ concentration [50], an effect involving p38/MAPK, SGK1 and nuclear factor of activated T cells 5 (NFAT5, TONEBP) [19]. Along those lines, high-salt diet fosters the infiltration of $\mathrm{T}_{\mathrm{H}} 17$ cells into the central nervous system and thus aggravates the course of experimental autoimmune encephalomyelitis [19]. At least in theory, mineralocorticoid excess may thus through upregulation of SGK1 predispose to autoimmune disease.

SGK1 is decisive for mineralocorticoid- and high-saltinduced tissue fibrosis $[41,51]$. Accordingly, gene-targeted mice lacking functional SGK1 are largely protected against cardiac [51] and renal [41] fibrosis following mineralocorticoid excess. Excessive SGK1 expression is observed in a wide variety of fibrosing tissues, such as lung fibrosis, diabetic nephropathy, glomerulonephritis, experimental nephrotic syndrome, obstructive nephropathy, liver cirrhosis, fibrosing pancreatitis, peritoneal fibrosis, Crohn's disease and celiac disease [41, 45, 46, 5153]. SGK1 expression is upregulated by transforming growth factor $\beta$ (TGF- $\beta$ ) [46], a powerful stimulator of tissue fibrosis [11, 54-59]. The fibrosing effect of TGF- $\beta$ is partially mediated by upregulation of the transcription factors Smad2/3 [45]. Those transcription factors are degraded by the ubiquitin ligase Nedd4L $[7,45]$. Nedd4L is phosphorylated and thus inactivated by SGK1, which thus amplifies the TGF- $\beta$ effects [45]. SGK1 further activates nuclear factor- $\kappa \mathrm{B}$ (NFkB) [46], a transcription factor fostering inflammation and fibrosis [45, 60, 61]. SGK1 phosphorylates and thus activates the kinase IKK, which

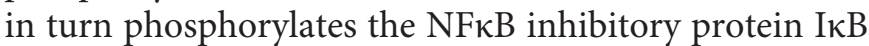
$[46,51]$. The phosphorylation triggers the degradation of $\mathrm{I} \kappa \mathrm{B}$, thus leading to disinhibition and nuclear translocation of NFKB $[46,51]$. NFkB-sensitive genes include connective tissue growth factor (CTGF), which is involved in fibrosis $[46,51]$. SGK1-dependent expression of CTGF contributes to the mineralocorticoid stimulation of cardiac fibrosis $[46,51]$ and aging of the skin [62]. SGK1 is further involved in angiotensin II-induced cardiac CTGF formation and fibrosis $[63,64]$ as well as in cardiac remodeling following increased afterload $[45,65,66]$.
Artunc/Lang 


\section{Mineralocorticoid Receptor as a Target for Anti- Inflammatory Treatment}

Mineralocorticoid-induced inflammation and tissue fibrosis is blunted or even reversed by inhibitors of the mineralocorticoid receptor, such as spironolactone or eplerenone [29, 42, 67-73]. At least in theory, untoward mineralocorticoid effects could be abrogated by inter- ference with mineralocorticoid receptor-dependent signaling, such as inhibition of SGK1 [74]. In view of the existing knowledge, it is tempting to speculate that mineralocorticoid receptor blockade or inhibition of mineralocorticoid receptor-dependent signaling favorably influences the clinical course of autoimmune and fibrosing disease.

\section{References}

1 Briet M, Schiffrin EL: Aldosterone: effects on the kidney and cardiovascular system. Nat Rev Nephrol 2010;6:261-273.

-2 Pearce D, Bhargava A, Cole TJ: Aldosterone: its receptor, target genes, and actions. Vitam Horm 2003;66:29-76.

-3 Tomaschitz A, Ritz E, Pieske B, Rus-Machan J, Kienreich K, Verheyen N, Gaksch M, Grubler M, Fahrleitner-Pammer A, Mrak P, Toplak H, Kraigher-Krainer E, Marz W, Pilz $S$ : Aldosterone and parathyroid hormone interactions as mediators of metabolic and cardiovascular disease. Metabolism 2014;63:2031.

4 Sakai RR, McEwen BS, Fluharty SJ, Ma LY: The amygdala: site of genomic and nongenomic arousal of aldosterone-induced sodium intake. Kidney Int 2000;57:1337-1345.

5 Vallon V, Huang DY, Grahammer F, Wyatt AW, Osswald H, Wulff P, Kuhl D, Lang F: SGK1 as a determinant of kidney function and salt intake in response to mineralocorticoid excess. Am J Physiol Regul Integr Comp Physiol 2005;289:R395-R401.

-6 Funder JW: Aldosterone, hypertension and heart failure: insights from clinical trials. Hypertens Res 2010;33:872-875.

7 Lang F, Stournaras C, Alesutan I: Regulation of transport across cell membranes by the serum- and glucocorticoid-inducible kinase SGK1. Mol Membr Biol 2014;31:29-36.

8 Azibani F, Fazal L, Chatziantoniou C, Samuel JL, Delcayre C: Aldosterone mediates cardiac fibrosis in the setting of hypertension. Curr Hypertens Rep 2013;15:395-400.

-9 Bae EH, Kim IJ, Joo SY, Kim EY, Kim CS, Choi JS, Ma SK, Kim SH, Lee JU, Kim SW: Renoprotective effects of sildenafil in DOCAsalt hypertensive rats. Kidney Blood Press Res 2012;36:248-257.

10 Briet M, Schiffrin EL: Vascular actions of aldosterone. J Vasc Res 2013;50:89-99.

$\checkmark 11$ Chen H, Zhou Y, Chen KQ, An G, Ji SY, Chen QK: Anti-fibrotic effects via regulation of transcription factor Sp1 on hepatic stellate cells. Cell Physiol Biochem 2012;29:51-60.
2 Lahmer T, Hermans R, Schmaderer C, Chang J, Stock K, Lutz J, Heemann U, Baumann M: Mineralocorticoid receptor antagonism and aldosterone synthesis inhibition do not improve glomerulosclerosis and renal interstitial fibrosis in a model of chronic kidney allograft injury. Kidney Blood Press Res 2012; 35:561-567.

13 Makowka A, Olejniczak-Fortak M, Nowicki $\mathrm{M}$ : A comparison of the antihypertensive and anti-inflammatory effects of aliskiren and ramipril add-on therapy in peritoneal dialysis patients - a pilot open label study. Kidney Blood Press Res 2012;36:18-25.

14 Okazaki A, Mori Y, Nakata M, Kimura T, Sonomura K, Sakoda C, Matsuoka E, Ishida M, Yamahara H, Kishimoto N, Nakagawa H, Matsubara H: Peritoneal mesothelial cells as a target of local aldosterone action: upregulation of connective tissue growth factor expression via serum- and glucocorticoid-inducible protein kinase 1. Kidney Blood Press Res 2009;32:151-160.

$\checkmark 15$ Schiffrin EL: Immune mechanisms in hypertension and vascular injury. Clin Sci (Lond) 2014; 126:267-274.

16 Schiffrin EL: The immune system: role in hypertension. Can J Cardiol 2013;29:543-548.

17 Yamahara H, Kishimoto N, Nakata M, Okazaki A, Kimura T, Sonomura K, Matsuoka E, Shiotsu Y, Adachi T, Matsubara H, Iwasaka T, Mori Y: Direct aldosterone action as a profibrotic factor via ROS-mediated SGK1 in peritoneal fibroblasts. Kidney Blood Press Res 2009;32:185-193.

18 Amador CA, Barrientos V, Pena J, Herrada AA, Gonzalez M, Valdes S, Carrasco L, Alzamora R, Figueroa F, Kalergis AM, Michea L: Spironolactone decreases DOCA-salt-induced organ damage by blocking the activation of T-helper 17 and the downregulation of regulatory $\mathrm{T}$ lymphocytes. Hypertension 2014;63:797-803.

19 Kleinewietfeld M, Manzel A, Titze J, Kvakan $\mathrm{H}$, Yosef N, Linker RA, Muller DN, Hafler DA: Sodium chloride drives autoimmune disease by the induction of pathogenic TH17 cells. Nature 2013;496:518-522.
20 Liu G, Liu G, Alzoubi K, Umbach AT, Pelzl L, Borst O, Gawaz M, Lang F: Upregulation of store operated Ca channel Orail, stimulation of Ca entry and triggering of cell membrane scrambling in platelets by mineralocorticoid DOCA. Kidney Blood Press Res 2014;38:2130.

21 Langer HF, Bigalke B, Seizer P, Stellos K, Fateh-Moghadam S, Gawaz M: Interaction of platelets and inflammatory endothelium in the development and progression of coronary artery disease. Semin Thromb Hemost 2010; 36:131-138.

-22 Seizer P, Gawaz M, May AE: Platelet-monocyte interactions - a dangerous liaison linking thrombosis, inflammation and atherosclerosis. Curr Med Chem 2008;15:1976-1980.

23 Koenig JB, Jaffe IZ: Direct role for smooth muscle cell mineralocorticoid receptors in vascular remodeling: novel mechanisms and clinical implications. Curr Hypertens Rep 2014; 16:427.

24 Brown NJ: Contribution of aldosterone to cardiovascular and renal inflammation and fibrosis. Nat Rev Nephrol 2013;9:459-469.

25 Kiyomoto H, Rafiq K, Mostofa M, Nishiyama A: Possible underlying mechanisms responsible for aldosterone and mineralocorticoid receptor-dependent renal injury. J Pharmacol Sci 2008;108:399-405

26 Lee TM, Chung TH, Lin SZ, Chang NC: Endothelin receptor blockade ameliorates renal injury by inhibition of RhoA/Rho-kinase signalling in deoxycorticosterone acetate-salt hypertensive rats. J Hypertens 2014;32:795805

27 Grossmann C, Gekle M: Non-classical actions of the mineralocorticoid receptor: misuse of EGF receptors? Mol Cell Endocrinol 2007; 277:6-12.

28 Williams JS: Evolving research in nongenomic actions of aldosterone. Curr Opin Endocrinol Diabetes Obes 2013;20:198-203.

29 Bansal S, Lindenfeld J, Schrier RW: Sodium retention in heart failure and cirrhosis: potential role of natriuretic doses of mineralocorticoid antagonist? Circ Heart Fail 2009;2:370376 
-30 McCurley A, Jaffe IZ: Mineralocorticoid receptors in vascular function and disease. Mol Cell Endocrinol 2012;350:256-265.

- 31 McCurley A, McGraw A, Pruthi D, Jaffe IZ: Smooth muscle cell mineralocorticoid receptors: role in vascular function and contribution to cardiovascular disease. Pflugers Arch 2013;465:1661-1670.

-32 Bienvenu LA, Reichelt ME, Delbridge LM, Young MJ: Mineralocorticoid receptors and the heart, multiple cell types and multiple mechanisms: a focus on the cardiomyocyte. Clin Sci (Lond) 2013;125:409-421.

33 Dabrowski R, Szwed H: Antiarrhythmic potential of aldosterone antagonists in atrial fibrillation. Cardiol J 2012;19:223-229.

34 Essick EE, Sam F: Cardiac hypertrophy and fibrosis in the metabolic syndrome: a role for aldosterone and the mineralocorticoid receptor. Int J Hypertens 2011;2011:346985.

35 Galuppo P, Bauersachs J: Mineralocorticoid receptor activation in myocardial infarction and failure: recent advances. Eur J Clin Invest 2012;42:1112-1120.

- 36 Messaoudi S, Azibani F, Delcayre C, Jaisser F: Aldosterone, mineralocorticoid receptor, and heart failure. Mol Cell Endocrinol 2012;350: 266-272.

-37 Nguyen Dinh Cat A, Jaisser F: Extrarenal effects of aldosterone. Curr Opin Nephrol Hypertens 2012;21:147-156.

- 38 Young MJ, Lam EY, Rickard AJ: Mineralocorticoid receptor activation and cardiac fibrosis. Clin Sci (Lond) 2007;112:467-475.

-39 Young MJ, Rickard AJ: Mechanisms of mineralocorticoid salt-induced hypertension and cardiac fibrosis. Mol Cell Endocrinol 2012; 350:248-255.

-40 Zannad F, Gattis Stough W, Rossignol P, Bauersachs J, McMurray JJ, Swedberg K, Struthers AD, Voors AA, Ruilope LM, Bakris GL, O'Connor CM, Gheorghiade M, Mentz RJ, Cohen-Solal A, Maggioni AP, Beygui F, Filippatos GS, Massy ZA, Pathak A, Pina IL, Sabbah HN, Sica DA, Tavazzi L, Pitt B: Mineralocorticoid receptor antagonists for heart failure with reduced ejection fraction: integrating evidence into clinical practice. Eur Heart J 2012;33:2782-2795.

-41 Artunc F, Amann K, Nasir O, Friedrich B, Sandulache D, Jahovic N, Risler T, Vallon V, Wulff P, Kuhl D, Lang F: Blunted DOCA/high salt induced albuminuria and renal tubulointerstitial damage in gene-targeted mice lacking SGK1. J Mol Med (Berl) 2006;84:737-746.

-42 Nishiyama A, Hitomi H, Rahman A, Kiyomoto $\mathrm{H}$ : Drug discovery for overcoming chronic kidney disease: pharmacological effects of mineralocorticoid-receptor blockers. J Pharmacol Sci 2009;109:1-6.

-43 Rafiq K, Hitomi H, Nakano D, Nishiyama A: Pathophysiological roles of aldosterone and mineralocorticoid receptor in the kidney. J Pharmacol Sci 2011;115:1-7.
44 Ronconi V, Turchi F, Appolloni G, di Tizio V, Boscaro M, Giacchetti G: Aldosterone, mineralocorticoid receptor and the metabolic syndrome: role of the mineralocorticoid receptor antagonists. Curr Vasc Pharmacol 2012;10:238-246.

45 Lang F, Stournaras C: Serum and glucocorticoid inducible kinase, metabolic syndrome, inflammation, and tumor growth. Hormones (Athens) 2013;12:160-171.

46 Lang F, Bohmer C, Palmada M, Seebohm G, Strutz-Seebohm N, Vallon V: (Patho)physiological significance of the serum- and glucocorticoid-inducible kinase isoforms. Physiol Rev 2006;86:1151-1178.

47 Liu SL, Schmuck S, Chorazcyzewski JZ, Gros $\mathrm{R}$, Feldman RD: Aldosterone regulates vascular reactivity: short-term effects mediated by phosphatidylinositol 3-kinase-dependent nitric oxide synthase activation. Circulation 2003;108:2400-2406.

48 Mutoh A, Isshiki M, Fujita T: Aldosterone enhances ligand-stimulated nitric oxide production in endothelial cells. Hypertens Res 2008;31:1811-1820.

49 Pasham V, Rotte A, Gu S, Yang W, Bhandaru M, Rexhepaj R, Pathare G, Lang F: Upregulation of intestinal NHE3 following saline ingestion. Kidney Blood Press Res 2013;37:4857.

50 Wu C, Yosef N, Thalhamer T, Zhu C, Xiao S, Kishi Y, Regev A, Kuchroo VK: Induction of pathogenic TH17 cells by inducible salt-sensing kinase SGK1. Nature 2013;496:513-517.

51 Vallon V, Wyatt AW, Klingel K, Huang DY, Hussain A, Berchtold S, Friedrich B, Grahammer F, Belaiba RS, Gorlach A, Wulff P, Daut J, Dalton ND, Ross J Jr, Flogel U, Schrader J, Osswald H, Kandolf R, Kuhl D, Lang F: SGK1-dependent cardiac CTGF formation and fibrosis following DOCA treatment. J Mol Med (Berl) 2006;84:396-404.

52 Cheng J, Truong LD, Wu X, Kuhl D, Lang F, $\mathrm{Du}$ J: Serum- and glucocorticoid-regulated kinase 1 is upregulated following unilateral ureteral obstruction causing epithelial-mesenchymal transition. Kidney Int 2010;78: 668-678.

53 Szebeni B, Vannay A, Sziksz E, Prokai A, Cseh A, Veres G, Dezsofi A, Gyorffy H, Szabo IR, Arato A: Increased expression of serum- and glucocorticoid-regulated kinase- 1 in the duodenal mucosa of children with coeliac disease. J Pediatr Gastroenterol Nutr 2010;50:147153.

54 Akhurst RJ, Hata A: Targeting the TGF- $\beta$ signalling pathway in disease. Nat Rev Drug Discov 2012;11:790-811.

55 Li W, Cui M, Wei Y, Kong X, Tang L, Xu D: Inhibition of the expression of TGF- $\beta_{1}$ and CTGF in human mesangial cells by exendin-4, a glucagon-like peptide-1 receptor agonist. Cell Physiol Biochem 2012;30:749757.
56 MacDonald EM, Cohn RD: TGF- $\beta$ signaling: its role in fibrosis formation and myopathies. Curr Opin Rheumatol 2012;24:628-634.

57 Rassler B, Marx G, Schierle K, Zimmer HG: Catecholamines can induce pulmonary remodeling in rats. Cell Physiol Biochem 2012; 30:1134-1147.

58 Roos M, Heinemann FM, Lindemann M, Horn PA, Lutz J, Stock K, Thurmel K, Baumann M, Witzke O, Heemann U: Fetuin-A pretransplant serum levels, kidney allograft function and rejection episodes: a 3-year posttransplantation follow-up. Kidney Blood Press Res 2011;34:328-333.

59 Wang HR, Chen DL, Zhao M, Shu SW, Xiong SX, Gan XD, Chao SP, Cao JL: C-reactive protein induces interleukin- 6 and thrombospondin-1 protein and mRNA expression through activation of nuclear factor- $\mathrm{\kappa B}$ in HK-2 cells. Kidney Blood Press Res 2012;35:211-219.

60 Shih VF, Tsui R, Caldwell A, Hoffmann A: A single NFKB system for both canonical and non-canonical signaling. Cell Res 2011;21: 86-102.

61 Stone KP, Kastin AJ, Pan W: NFאB is an unexpected major mediator of interleukin-15 signaling in cerebral endothelia. Cell Physiol Biochem 2011;28:115-124.

-62 Tsai V, Parker WE, Orlova KA, Baybis M, Chi AW, Berg BD, Birnbaum JF, Estevez J, Okochi K, Sarnat HB, Flores-Sarnat L, Aronica E, Crino PB: Fetal brain mTOR signaling activation in tuberous sclerosis complex. Cereb Cortex 2014;24:315-327.

63 Chilukoti RK, Mostertz J, Bukowska A, Aderkast C, Felix SB, Busch M, Volker U, Goette A, Wolke C, Homuth G, Lendeckel U: Effects of irbesartan on gene expression revealed by transcriptome analysis of left atrial tissue in a porcine model of acute rapid pacing in vivo. Int J Cardiol 2013;168:2100-2108.

-64 Yang M, Zheng J, Miao Y, Wang Y, Cui W, Guo J, Qiu S, Han Y, Jia L, Li H, Cheng J, Du J: Serum-glucocorticoid regulated kinase-1 regulates alternatively activated macrophage polarization contributing to angiotensin IIinduced inflammation and cardiac fibrosis. Arterioscler Thromb Vasc Biol 2012;32: 1675-1686.

65 Das S, Aiba T, Rosenberg M, Hessler K, Xiao C, Quintero PA, Ottaviano FG, Knight AC, Graham EL, Bostrom P, Morissette MR, Del Monte F, Begley MJ, Cantley LC, Ellinor PT, Tomaselli GF, Rosenzweig A: Pathological role of serum- and glucocorticoid-regulated kinase 1 in adverse ventricular remodeling. Circulation 2012;126:2208-2219.

66 Voelkl J, Lin Y, Alesutan I, Ahmed MS, Pasham V, Mia S, Gu S, Feger M, Saxena A, Metzler B, Kuhl D, Pichler BJ, Lang F: Sgk1 sensitivity of $\mathrm{Na}^{+} / \mathrm{H}^{+}$exchanger activity and cardiac remodeling following pressure overload. Basic Res Cardiol 2012;107:236. 
67 Lucisano S, Buemi M, Passantino A, Aloisi C, Cernaro V, Santoro D: New insights on the role of vitamin $\mathrm{D}$ in the progression of renal damage. Kidney Blood Press Res 2013;37: 667-678.

68 Ma TK, Szeto CC: Mineralocorticoid receptor antagonist for renal protection. Ren Fail 2012; 34:810-817.

69 Markowitz M, Messineo F, Coplan NL: Aldosterone receptor antagonists in cardiovascular disease: a review of the recent literature and insight into potential future indications. Clin Cardiol 2012;35:605-609.
70 Nagata K: Mineralocorticoid antagonism and cardiac hypertrophy. Curr Hypertens Rep 2008;10:216-221.

71 Namsolleck P, Unger T: Aldosterone synthase inhibitors in cardiovascular and renal diseases. Nephrol Dial Transplant 2014;29(suppl 1):i62-i68.

72 Tylicki L, Lizakowski S, Rutkowski P, Renke M, Sulikowska B, Heleniak Z, Donderski R, Bednarski R, Przybylska M, Manitius J, Rutkowski B: The enhanced renin-angiotensinaldosterone system pharmacological blockade - which is the best? Kidney Blood Press Res 2012;36:335-343.
73 Young MJ: Mechanisms of mineralocorticoid receptor-mediated cardiac fibrosis and vascular inflammation. Curr Opin Nephrol Hypertens 2008;17:174-180.

74 Lang F, Voelkl J: Therapeutic potential of serum and glucocorticoid inducible kinase inhibition. Expert Opin Investig Drugs 2013;22: 701-714. 